UDC 336.027:316.442

LBC 65.012.2

\title{
EVALUATION OF THE DIFFERENTIATION OF SOCIAL PROTECTION OF THE POPULATION OF THE SOUTHERN MACROREGION OF RUSSIA
}

\author{
Natalya V. Gorshkova \\ Volgograd State University, Volgograd, Russian Federation \\ Leyla A. Mytareva \\ Volgograd State University, Volgograd, Russian Federation \\ Lyubov V. Grigoryeva \\ Volgograd State University, Volgograd, Russian Federation
}

\begin{abstract}
The urgency of the issues of maintaining an acceptable standard of living for certain groups of Russians has recently become increasingly important. The various social protection mechanisms used by the state (pensions, allowances, benefits, etc.) do not fully fulfill their mission, since the level of social protection provided varies from tens of rubles to thousands of rubles depending on the type of protection. The transformation of economic relations, the revision of certain aspects of the paternal system of social protection of the population from the standpoint of strengthening efficiency, expediency and targeting, as well as reorientation to new models of social protection based on partnership between the state, business and society require a unified approach. However, the high regional differentiation of the subjects of the Russian Federation by the population's living standards and the financial possibilities of the territories is quite a challenge. This argument is proved by the authors using the example of the Southern Federal District (SFD). To better illustrate the situation, the indicators for individual regions of the SFD were compared with the average values in Russia. The analysis of the provided social protection measures on the territory of the SFD makes it possible to identify the leading regions (the Krasnodar Krai, the Rostov Region) and the outsider regions (the Republics of Adygea and the Republics of Kalmykia). In addition, it has been found out that not all measures of social protection are applied in all regions of the Southern Federal District, in particular regional maternity capital and a one-time cash payment at the birth of the third and subsequent children until the child reaches the age of 3 years. To minimize $\infty$ the regional differentiation of the social protection provided, the authors propose such measures as the creation of a single information platform (base) of all measures of social protection of Russians in Russia; the unification and codification of social legislation at the level of the constituent entities of the Russian Federation; the creation of a regional and federal "social treasury" as an instrument for the transition of the Russian system of social protection from leveling measures to targeted ones.

Key words: social protection, social support, regional economy, territorial differentiation, social code.

УДК 336.027:316.442

ББК 65.012 .2
\end{abstract}

\section{ОЦЕНКА ДИФФЕРЕНЦИАЦИИ СОЦИАЛЬНОЙ ЗАЩИТЫ НАСЕЛЕНИЯ} ЮЖНОГО МАКРОРЕГИОНА РОССИИ

\author{
Наталья Валерьевна Горшкова
}

Волгоградский государственный университет, г. Волгоград, Российская Федерация

Лейла Акифовна Мытарева

Волгоградский государственный университет, г. Волгоград, Российская Федерация 


\section{Любовь Владимировна Григорьева}

Волгоградский государственный университет, г. Волгоград, Российская Федерация

Аннотация. Актуальность вопросов поддержания приемлемого уровня жизни отдельных групп россиян в последнее время приобретает все большую значимость. Применяемые государством различные механизмы социальной защиты (пенсии, пособия, льготы и т. д.), выполняют возложенную на них задачу не в полной мере, так как предоставляемый уровень социальной защиты, в зависимости от вида, варьируется от десятков рублей до тысяч. Трансформация экономических отношений, пересмотр отдельных аспектов патернальной системы социальной защиты населения с позиции усиления эффективности, целесообразности и адресности, а также переориентация на новые модели социальной защиты, основанные на партнерстве государства, бизнеса и общества, требуют единого подхода, однако наличие высокой региональной дифференциации субъектов Российской Федерации по уровню жизни населения и финансовых возможностей территорий осложняет эту задачу. Данный аргумент авторы доказали на примере Южного федерального округа (ЮФО), при этом для наглядности показатели по отдельным регионам ЮФО сравнивались со средними значениями по России. Приведенный анализ предоставляемых мер социальной защиты на территории ЮФО позволил выявить регионы-лидеры (Краснодарский край, Ростовская область) и регионы-аутсайдеры (Республики Адыгея и Калмыкия). Помимо этого, было выявлено, что не все меры социальной защиты применяются во всех регионах ЮФО, в частности региональный материнский капитал и единовременная денежная выплата при рождении третьего и последующих детей до достижения ребенком возраста 3 лет. Для минимизации региональной дифференциации предоставляемой социальной защиты авторами были предложены такие мероприятии, как создание единой информационной платформы (базы) обо всех действующих в России мерах социальной защиты россиян; унификация и кодификация социального законодательства на уровне субъектов Российской Федерации; создание федерального и региональных «социальных казначейств» как инструмента перехода российской системы социальной защиты от уравнительных мер к адресным.

Ключевые слова: социальная защита, социальная поддержка, региональная экономика, территориальная дифференциация, социальный кодекс.

В самом общем виде под социальной защитой населения понимается совокупность государственных и негосударственных мер по гарантированию и обеспечению достойного уровня жизни гражданам конкретного государства. Размер гарантируемых государством параметров достойной жизни граждан, широта охвата категорий населения мерами по обеспечению достойного проживания, а также степень участия в этом процессе негосударственных структур (как правило, работодателей, самих граждан и их объединений) все это определяется каждым государством индивидуально, исходя из степени его социальной направленности, реально сложившихся потребностей граждан в такой защите и финансовых возможностей государства удовлетворить эти потребности, а также уровня социальной ответственности бизнеса и граждан. По общей практике сложившиеся в той или иной странепринципы организации и функционирования программ социальной защиты населения именуются моделями социальной защиты [1]. Так, известны четыре основные модели социальной защиты населения стран Европейского союза: континентальная (немец- кая модель, модель Бисмарка), англосаксонская (английская модель, модель Бевериджа), скандинавская и южно-европейская.

Конституцией Российской Федерации в ст. 2 высшей ценностью признается человек, его права и свободы, в ст. 7 зафиксировано, что Россия - «социальное государство, политика которого направлена на создание условий, обеспечивающих достойную жизнь и свободное развитие человека», и в ней «охраняются труд и здоровье людей, устанавливается гарантированный минимальный размер оплаты труда, обеспечивается государственная поддержка семьи, материнства, отцовства и детства, инвалидов и пожилых граждан, развивается система социальных служб, устанавливаются государственные пенсии, пособия и иные гарантии социальной защиты». Ст. 39 Конституции РФ гласит, что «каждому гарантируется социальное обеспечение по возрасту, в случае болезни, инвалидности, потери кормильца, для воспитания детей и в иных случаях, установленных законом». В ст. 72 Конституции РФ указано, что в совместном ведении Российской Федерации и субъектов Российской Федерации находится в том числе «защита семьи, материнства, отцов- 
ства и детства; социальная защита, включая социальное обеспечение».

Наследием СССР является высокий уровень государственной ответственности за качество и уровень жизни граждан, вследствие чего в России по умолчанию под социальной защитой населения зачастую понимают исключительно государственную деятельность, в то время как технически социальная защита россиян может формироваться в негосударственном секторе как бизнесом [3] (организациями, их объединениями), так и самими гражданами и их объединениями (например, профсоюзами работников) (рис. 1).

Вследствие федеративного устройства нашего государства социальная защита россиян может рассматриваться как деятельность законодательных и исполнительных государственных органов власти (на федеральном уровне и уровнях субъектов Федерации региональных) и органов власти местного самоуправления (муниципальный уровень), направленная на формирование свободного развития личности, предоставление возможности для самоопределения индивидов и создание условий достойной жизни граждан путем обеспечения законодательно установленных и экономически обоснованных социальных гарантий двух типов: общих минимальных гарантий для всех граждан страны и специфических общественных гарантий и льгот для отдельных категорий (групп) граждан (как правило, социально уязвимых и/или общественно значимых категорий лиц).

Федеративное устройство российского государства, детерминирующее финансовую самостоятельность бюджетов субъектов Федерации и муниципальных образований в рамках бюджетной системы, а также специфика выделения в бюджетной системе финансирования целевых расходов государства в форме бюджетов специализированных внебюджетных фондов - Пенсионного фонда России, Фонда социального страхования и Фонда обязательного медицинского страхования - породили разделение государственных гарантий в сфере социальной защиты россиян на несколько уровней: федерально установленные государственные гарантии и гарантии, устанавливаемые субъектами Федерации, а в некоторых случаях и муниципалитетами. По общему правилу на уровне субъектов Федерации государственные гарантии не могут быть ниже федерально установленных (выше могут быть). При

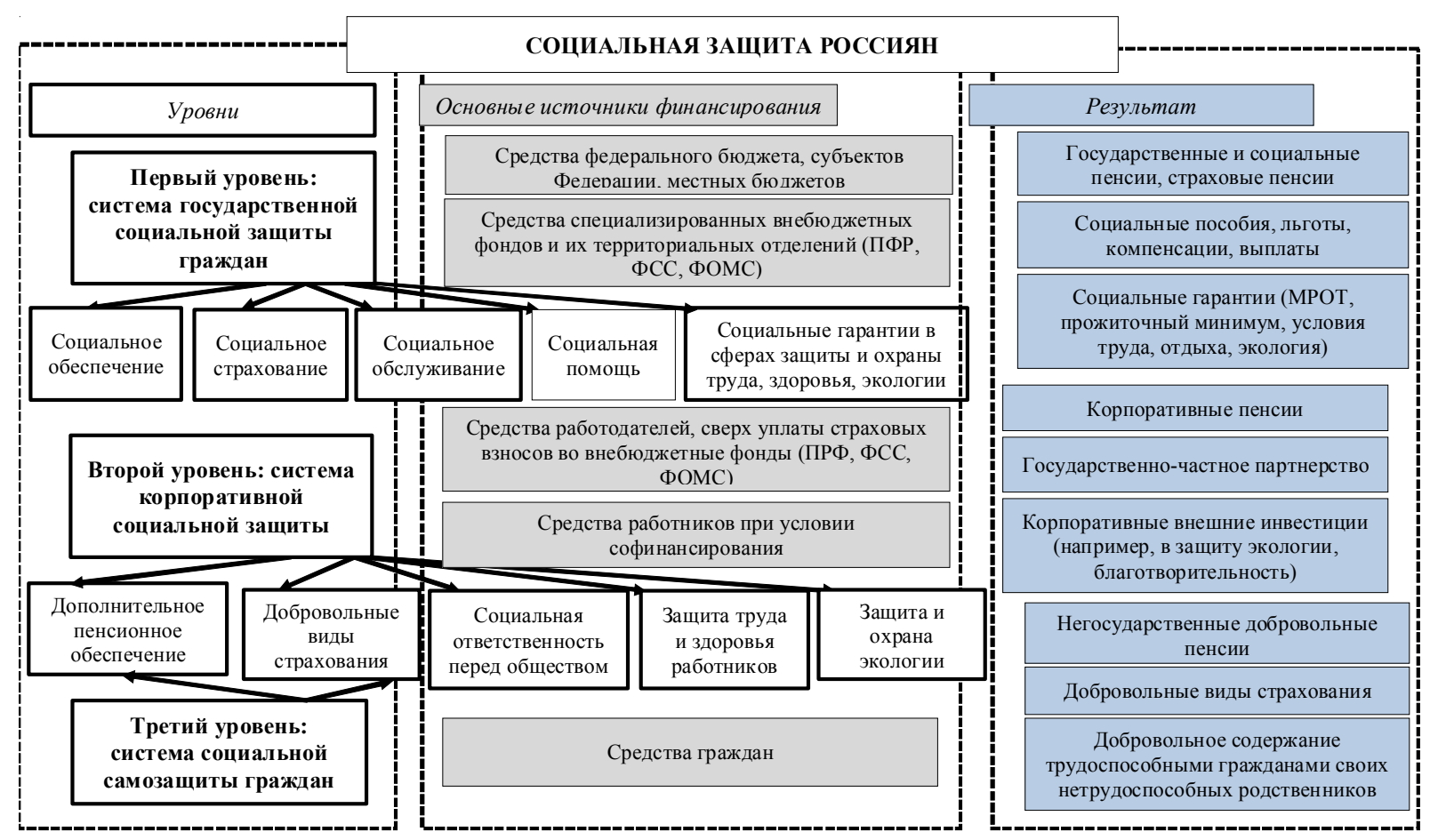

Рис. 1. Социальная защита населения в современной России

Примечание. Построено авторами. 
этом если средств регионального бюджета не хватает на обеспечение населения региона мерами социальной защиты в рамках федерально установленного минимума, федеральный уровень субсидирует региональные бюджеты. Другое правило действует в отношении местных мер социальной защиты - они добровольно вводятся органами местного самоуправления в дополнение к государственным (федеральным и региональным мерам).

В условиях неравномерного распределения населения по территории России, неоднородности самого населения по его структуре с позиции доли граждан, на которых распространяются категориальные меры соцзащиты, а также при разных финансовых возможностях бюджетной системы региона возникает сильная дифференциация территорий по уровню социальной защищенности ее жителей. Пример такой дифференциации можно проиллюстрировать на Южном федеральном округе (ЮФО). Для наглядности показатели по отдельным регионам ЮФО будут сравниваться со средним значением по России или с федерально установленными величинами.

По данным 2016 г. 16,4 млн человек являются жителями ЮФО, что составляет 11,2 \% россиян, при этом пенсионеры региона составляют такую же долю от числа всех пенсионеров России. Структурный состав населения региона по определенным группам лиц (пенсионеры, инвалиды и дети) не имеет сильного отличия от общероссийского (см. табл. 1), но при этом только по двум показателям доля населения по ЮФО больше, чем в целом по России. Это доля пожилого населения $(26,2 \%$ от населения ЮФО против $25 \%$ в среднем по России) и доля лиц, реабилитированных после репрессий $(0,4 \%$ против $0,3 \%$ по стране). По таким показателям, как доля пенсионеров $(31,1 \%)$, численность детей-инвалидов $(0,4 \%)$, численность лиц, получающих региональный материнский капитал $(0,1 \%)$, расхождений на уровне ЮФО и РФ нет. В остальных случаях показатели по Южному макрорегиону немного ниже общероссийских.

В разрезе субъектов ЮФО существует региональная дифференциация как по численному распределению населения по субъектам, так и по структуре населения по регионам в разрезе основных групп населения, выделяемых для социальной защиты. Больше всего жителей ЮФО (см. табл. 2) проживают в Краснодарском крае (5,6 млн чел., что составляет $34 \%$ от населения всего ЮФО), меньше всего - в Республике Калмыкия (0,27 млн чел., что составляет 1,6\% от населения всего ЮФО). Распределение населения по социально значимым группам на территории ЮФО характеризуется следующими особенностями: больше всего пенсионеров проживают в Краснодарском крае (1,7 млн челю), меньше всего - в трех регионах: Республике Калмыкия, г. Севастополе и Республике Адыгея (в среднем около 0,1 млн чел. на регион); больше всего детей, получающих ежемесячное пособие, проживают также в Краснодарском крае (0,3 млн чел.), меньше всего - в г. Севастополе (0,01 млн чел.); по численности инвалидов лидирует Краснодарский край и Ростовская область (по 0,4 млн чел.), меньше всего инвалидов проживают в Республике Калмыкия (0,02 млн чел.).

Оценку дифференциации населения по численности необходимо дополнить анализом и сопоставлением долей социально значимых категорий населения от общей численности жителей конкретного региона ЮФО (см. табл. 3).

Как видно из представленных данных, дифференциация регионов ярко выражена по категориям: доля пенсионеров от общей численности жителей региона - в Волгоградской области это всего 23 \% населения, а в Астраханской области уже 33 \%; в Республике Калмыкия доля детей почти $21 \%$ от всего населения, а в Волгоградской области $16 \%$; доля детей с назначенными пособиями в Волгоградской области всего $2 \%$ от числа жителей, в Краснодарском крае около 8 \%; численность инвалидов в Волгоградской области составляет менее $5 \%$ от общей численности, а в Астраханской области почти $10 \%$; также в Астраханской области чрезвычайно высока доля реабилитированных лиц после репрессий $-7 \%$, в то время как в других регионах этот показатель максимум достигает $0,5 \%$. По некоторым показателям финансовой поддержки материнства (выплаченным единовременным пособиям при рождении ребенка, пособиям при ранней постановке женщин на учет в медицинских учреждениях, получателям выплат за третьего и последующих детей) регионы ЮФО имеют сопоставимые значения. 
Вклад ЮФО по категориям населения в общероссийскую совокупность и структура населения по категориям в РФ и ЮФО в 2016 г., \%

\begin{tabular}{|c|c|c|c|c|}
\hline \multirow[t]{2}{*}{ Группы населения } & \multirow[t]{2}{*}{$\begin{array}{l}\text { Доля } \\
\text { ЮФО } \\
\text { в РФ }\end{array}$} & \multicolumn{2}{|c|}{$\begin{array}{l}\text { Доля каждой категории в } \\
\text { общей численности насе- } \\
\text { ления территории }\end{array}$} & \multirow{2}{*}{$\begin{array}{l}\text { Абсолютное откло- } \\
\text { нение показателя в } \\
\text { ЮФО от общерос- } \\
\text { сийского уровня }\end{array}$} \\
\hline & & РФ & ЮФО & \\
\hline Население, всего & 11,2 & 100 & 100 & - \\
\hline Население, занятое в экономике & 10,5 & 49,3 & 46,3 & -3 \\
\hline Население-пенсионеры & 11,2 & 31,1 & 31,1 & $\underline{0}$ \\
\hline Население младше трудоспособного возраста & 10,9 & 18,3 & 17,9 & $-0,4$ \\
\hline Население трудоспособного возраста & 11,0 & 56,7 & 55,9 & $-0,8$ \\
\hline Население старше трудоспособного возраста & 11,7 & 25,0 & 26,2 & 1,2 \\
\hline $\begin{array}{l}\text { Дети до } 16 \text { лет с назначенными ежемесяч- } \\
\text { ными пособиями }\end{array}$ & 11,7 & 5,2 & 5,5 & 0,3 \\
\hline Население-инвалиды, всего & 10,6 & 8,4 & 7,9 & $-0,5$ \\
\hline Население с I группой инвалидности & 10,0 & 0,9 & 0,8 & $-0,1$ \\
\hline Население со II группой инвалидности & 10,2 & 4,0 & 3,7 & $-0,3$ \\
\hline Население с III группой инвалидности & 9,1 & 3,0 & 2,4 & $-0,6$ \\
\hline Население - дети-инвалиды & 10,0 & 0,4 & 0,4 & $\underline{0}$ \\
\hline Население - труженики тыла * & 8,8 & 0,5 & 0,4 & $-0,1$ \\
\hline Население - ветераны труда * & 8,6 & 7,9 & 6,1 & $-1,8$ \\
\hline $\begin{array}{l}\text { Население - реабилитированные лица и ли- } \\
\text { ца, признанные пострадавшими от политиче- } \\
\text { ских репрессий * }\end{array}$ & 12,0 & 0,3 & 0,4 & $\mathbf{0 , 1}$ \\
\hline $\begin{array}{l}\text { Население, получившее региональный мате- } \\
\text { ринский капитал }\end{array}$ & 6,7 & 0,1 & 0,1 & $\underline{0}$ \\
\hline $\begin{array}{l}\text { Выплаченные единовременные пособия при } \\
\text { рождении ребенка }\end{array}$ & 10,5 & 1,2 & 1,1 & $-0,1$ \\
\hline $\begin{array}{l}\text { Полученные единовременные пособия, вы- } \\
\text { плаченные женщинам, вставшим на учет в } \\
\text { медицинских учреждениях в ранние сроки } \\
\text { беременности (до } 12 \text { недель) }\end{array}$ & 9,4 & 0,6 & 0,5 & $-0,1$ \\
\hline $\begin{array}{l}\text { Население - получатели ежемесячных посо- } \\
\text { бий по уходу за ребенком до достижения им } \\
\text { возраста } 1,5 \text { лет }\end{array}$ & 9,5 & 2,9 & 2,4 & $-0,5$ \\
\hline $\begin{array}{l}\text { Население - получатели ежемесячных де- } \\
\text { нежных выплат при рождении третьего и по- } \\
\text { следующих детей до достижения ребенком } \\
\text { возраста } 3 \text { лет }\end{array}$ & 16,0 & 0,3 & 0,5 & 0,2 \\
\hline $\begin{array}{l}\text { Численность населения с денежными дохо- } \\
\text { дами ниже прожиточного минимума }\end{array}$ & 12,7 & 13,4 & 15,2 & 1,8 \\
\hline
\end{tabular}

Примечания. * - население, отнесенное к компетенции субъектов РФ, имеющее право на меры социальной поддержки; полужирным выделены ситуации превышения регионального значения над общероссийским; подчеркиванием выделены равные значения рассматриваемых категорий. Рассчитано авторами по: [8]. 
Н.В. Горшкова, Л.А. Мытарева, Л.В. Григорьева. Дифференциация социальной защиты населения

Таблица 2

Региональная дифференциация населения ЮФО в 2016 г., млн чел.

\begin{tabular}{|c|c|c|c|c|c|c|c|c|c|c|}
\hline Группы населения & РФ & ЮФО & PA & РКя & РКм & КК & $\mathrm{AO}$ & BO & $\mathrm{PO}$ & $\mathrm{C}$ \\
\hline Население, всего & 146,8 & 16,4 & 0,45 & 0,27 & 1,9 & 5,57 & 1,019 & 2,53 & 4,2 & 0,43 \\
\hline Население, занятое в экономике & 72,4 & 7,6 & 0,2 & 0,1 & 0,8 & 2,6 & 0,5 & 1,2 & 2 & 0,2 \\
\hline Население-пенсионеры & 45,7 & 5,1 & 0,1 & 0,1 & 0,6 & 1,7 & 0,3 & 0,8 & 1,4 & 0,1 \\
\hline $\begin{array}{l}\text { Население младше трудоспо- } \\
\text { собного возраста }\end{array}$ & 26,86 & 2,94 & 0,09 & 0,06 & 0,34 & 1,03 & 0,21 & 0,43 & 0,71 & 0,07 \\
\hline $\begin{array}{l}\text { Население трудоспособного } \\
\text { возраста }\end{array}$ & 83,24 & 9,17 & 0,25 & 0,15 & 1,04 & 3,1 & 0,57 & 1,42 & 2,37 & 0,24 \\
\hline $\begin{array}{l}\text { Население старше трудоспособ- } \\
\text { ного возраста }\end{array}$ & 36,7 & 4,3 & 0,11 & 0,06 & 0,53 & 1,44 & 0,24 & 0,68 & 1,12 & 0,12 \\
\hline $\begin{array}{l}\text { Дети до } 16 \text { лет с назначенными } \\
\text { ежемесячными пособиями }\end{array}$ & 7,7 & 0,9 & 0,02 & 0,03 & 0,07 & 0,3 & 0,06 & 0,2 & 0,2 & 0,01 \\
\hline Население-инвалиды, всего & 12,3 & 1,3 & 0,04 & 0,02 & 0,1 & 0,4 & 0,05 & 0,2 & 0,4 & 0,02 \\
\hline $\begin{array}{l}\text { Население с I группой инвалид- } \\
\text { ности }\end{array}$ & 1,3 & 0,13 & 0,003 & 0,003 & 0,01 & 0,05 & 0,008 & 0,02 & 0,03 & 0,002 \\
\hline $\begin{array}{l}\text { Население со II группой инва- } \\
\text { лидности }\end{array}$ & 5,9 & 0,6 & 0,02 & 0,008 & 0,05 & 0,2 & 0,02 & 0,09 & 0,2 & 0,009 \\
\hline $\begin{array}{l}\text { Население с III группой инва- } \\
\text { лидности }\end{array}$ & 4,4 & 0,4 & 0,01 & 0,01 & 0,06 & 0,1 & 0,02 & 0,08 & 0,1 & 0,008 \\
\hline Население - дети-инвалиды & 0,6 & 0,06 & 0,002 & 0,002 & 0,006 & 0,02 & 0,004 & 0,008 & 0,01 & 0,001 \\
\hline Население - труженики тыла * & 0,8 & 0,07 & 0,002 & 0,001 & 0,008 & 0,002 & 0,007 & 0,02 & 0,02 & 0,001 \\
\hline Население - ветераны труда * & 11,6 & 1 & 0,03 & 0,02 & 0,07 & 0,4 & 0,07 & 0,1 & 0,02 & 0,005 \\
\hline $\begin{array}{l}\text { Население - реабилитированные } \\
\text { лица и лица, признанные по- } \\
\text { страдавшими от политических } \\
\text { репрессий* }\end{array}$ & 0,5 & 0,06 & 0,001 & 0,02 & 0,009 & 0,01 & 0,002 & 0,006 & 0,3 & 0 \\
\hline $\begin{array}{l}\text { Население, получившее регио- } \\
\text { нальный материнский капитал, } \\
\text { чел. }\end{array}$ & 175257 & 11713 & 84 & 216 & - & 2865 & 1777 & 5120 & 1651 & - \\
\hline $\begin{array}{l}\text { Выплаченные единовременные } \\
\text { пособия при рождении ребенка, } \\
\text { ед. }\end{array}$ & 1759438 & 183970 & 4350 & 2903 & 20453 & 72877 & 11578 & 22403 & 45214 & 4192 \\
\hline $\begin{array}{l}\text { Полученные единовременные } \\
\text { пособия, выплаченные женщи- } \\
\text { нам, вставшим на учет в меди- } \\
\text { цинских учреждениях в ранние } \\
\text { сроки беременности (до } 12 \text { не- } \\
\text { дель), ед. }\end{array}$ & 896855 & 83954 & 1788 & 1172 & 7317 & 35890 & 5055 & 10651 & 20275 & 1806 \\
\hline $\begin{array}{l}\text { Население - получатели ежеме- } \\
\text { сячных пособий по уходу за ре- } \\
\text { бенком до достижения им воз- } \\
\text { раста } 1,5 \text { лет }\end{array}$ & 4,2 & 0,4 & 0,1 & 0,006 & 0,03 & 0,2 & 0,03 & 0,05 & 0,1 & 0,007 \\
\hline $\begin{array}{l}\text { Население - получатели ежеме- } \\
\text { сячных денежных выплат при } \\
\text { рождении третьего и последую- } \\
\text { щих детей до достижения ре- } \\
\text { бенком возраста } 3 \text { лет }\end{array}$ & 0,5 & 0,08 & - & - & 0,006 & 0,04 & - & 0,01 & 0,02 & 0 \\
\hline $\begin{array}{l}\text { Численность населения с де- } \\
\text { нежными доходами ниже про- } \\
\text { житочного минимума }\end{array}$ & 19,7 & 2,5 & 0,1 & 0,1 & 0,4 & 0,6 & 0,2 & 0,4 & 0,6 & 0,1 \\
\hline
\end{tabular}

Примечания. РА - Республика Адыгея, РКя - Республика Калмыкия, РКм - Республика Крым, КК Краснодарский край, АО - Астраханская область, ВО - Волгоградская область, $\mathrm{PO}$ - Ростовская область, С г. Севастополь. * - население, отнесенное к компетенции субъектов РФ, имеющее право на меры социальной поддержки. Составлено авторами по: [8]. 


\section{Дифференциация структуры населения регионов ЮФО по социально значимым категориям в 2016 г., \%}

\begin{tabular}{|c|c|c|c|c|c|c|c|c|c|}
\hline \multirow{2}{*}{$\begin{array}{c}\text { Социально значимые категории } \\
\text { населения }\end{array}$} & \multicolumn{8}{|c|}{$\begin{array}{l}\text { Доля социально значимой категории населения } \\
\text { региона от общей численности жителей региона }\end{array}$} & \multirow[t]{2}{*}{ CP3 } \\
\hline & $\mathrm{PA}$ & РКя & РКм & КK & $\mathrm{AO}$ & $\mathrm{BO}$ & $\mathrm{PO}$ & $\mathrm{C}$ & \\
\hline Население, занятое в экономике & 44,4 & 37,0 & 42,1 & 46,7 & 49,1 & 47,4 & 47,6 & 46,5 & 45,1 \\
\hline Население-пенсионеры & 22,2 & 37,0 & 31,6 & 30,5 & 29,4 & 31,6 & 33,3 & 23,3 & 29,9 \\
\hline $\begin{array}{l}\text { Население младше трудоспособ- } \\
\text { ного возраста }\end{array}$ & 20,0 & 22,2 & 17,9 & 18,5 & 20,6 & 17,0 & 16,9 & 16,3 & 18,7 \\
\hline $\begin{array}{l}\text { Население трудоспособного воз- } \\
\text { раста }\end{array}$ & 55,6 & 55,6 & 54,7 & 55,7 & 55,9 & 56,1 & 56,4 & 55,8 & 55,7 \\
\hline $\begin{array}{l}\text { Население старше трудоспособно- } \\
\text { го возраста }\end{array}$ & 24,4 & 22,2 & 27,9 & 25,9 & 23,6 & 26,9 & 26,7 & 27,9 & 25,7 \\
\hline $\begin{array}{l}\text { Дети до } 16 \text { лет с назначенными } \\
\text { ежемесячными пособиями }\end{array}$ & 4,4 & 11,1 & 3,7 & 5,4 & 5,9 & 7,9 & 4,8 & 2,3 & 5,7 \\
\hline Население-инвалиды, всего & 8,9 & 7,4 & 5,3 & 7,2 & 4,9 & 7,9 & 9,5 & 4,7 & 7,0 \\
\hline $\begin{array}{l}\text { Население с I группой инвалидно- } \\
\text { сти }\end{array}$ & 0,7 & 1,1 & 0,5 & 0,9 & 0,8 & 0,8 & 0,7 & 0,5 & 0,7 \\
\hline $\begin{array}{l}\text { Население со II группой инвалид- } \\
\text { ности }\end{array}$ & 4,4 & 3,0 & 2,6 & 3,6 & 2,0 & 3,6 & 4,8 & 2,1 & 3,3 \\
\hline $\begin{array}{l}\text { Население с III группой инвалид- } \\
\text { ности }\end{array}$ & 2,2 & 3,7 & 3,2 & 1,8 & 2,0 & 3,2 & 2,4 & 1,9 & 2,5 \\
\hline Население - дети-инвалиды & 0,4 & 0,7 & 0,3 & 0,4 & 0,4 & 0,3 & 0,2 & 0,2 & 0,4 \\
\hline Население - труженики тыла & 0,4 & 0,4 & 0,4 & 0,0 & 0,7 & 0,8 & 0,5 & 0,2 & 0,4 \\
\hline Население - ветераны труда & 6,7 & 7,4 & 3,7 & 7,2 & 6,9 & 4,0 & 0,5 & 1,2 & 4,7 \\
\hline $\begin{array}{l}\text { Население - реабилитированные ли- } \\
\text { ца и лица, признанные пострадав- } \\
\text { шими от политических репрессий }\end{array}$ & 0,2 & 7,4 & 0,5 & 0,2 & 0,2 & 0,2 & 7,1 & 0,0 & 2,0 \\
\hline $\begin{array}{l}\text { Население, получившее регио- } \\
\text { нальный материнский капитал }\end{array}$ & 0,0 & 0,1 & - & 0,1 & 0,2 & 0,2 & 0,0 & - & 0,1 \\
\hline $\begin{array}{l}\text { Выплаченные единовременные } \\
\text { пособия при рождении ребенка }\end{array}$ & 1,0 & 1,1 & 1,1 & 1,3 & 1,1 & 0,9 & 1,1 & 1,0 & 1,1 \\
\hline $\begin{array}{l}\text { Полученные единовременные по- } \\
\text { собия, выплаченные женщинам, } \\
\text { вставшим на учет в медицинских } \\
\text { учреждениях в ранние сроки бе- } \\
\text { ременности (до } 12 \text { недель) }\end{array}$ & 0,4 & 0,4 & 0,4 & 0,6 & 0,5 & 0,4 & 0,5 & 0,4 & 0,5 \\
\hline $\begin{array}{l}\text { Население - получатели ежеме- } \\
\text { сячных пособий по уходу за ре- } \\
\text { бенком до достижения им возраста } \\
1,5 \text { лет }\end{array}$ & 22,2 & 2,2 & 1,6 & 3,6 & 2,9 & 2,0 & 2,4 & 1,6 & 4,8 \\
\hline $\begin{array}{l}\text { Население - получатели ежеме- } \\
\text { сячных денежных выплат при ро- } \\
\text { ждении третьего и последующих } \\
\text { детей до достижения ребенком } \\
\text { возраста } 3 \text { лет }\end{array}$ & - & - & 0,3 & 0,7 & - & 0,4 & 0,5 & 0,0 & 0,4 \\
\hline $\begin{array}{l}\text { Доля населения с денежными до- } \\
\text { ходами ниже прожиточного ми- } \\
\text { нимума от числа жителей региона }\end{array}$ & 13,7 & 31,2 & 22,2 & 11,6 & 16,2 & 15,3 & 14,0 & 13,7 & 17,2 \\
\hline $\begin{array}{l}\text { Справочно: доля всего населения } \\
\text { региона в общей численности на- } \\
\text { селения ЮФО }\end{array}$ & 2,7 & 1,6 & 11,6 & 34,0 & 6,2 & 15,4 & 25,6 & 2,6 & - \\
\hline
\end{tabular}

Примечания. РА - Республика Адыгея, РКя - Республика Калмыкия, РКм - Республика Крым, КК Краснодарский край, АО - Астраханская область, ВО - Волгоградская область, РО - Ростовская область, С г. Севастополь, СР3 - среднее региональное значение. Рассчитано по данным таблицы 2. 
Н.В. Горшкова, Л.А. Мытарева, Л.В. Григорьева. Дифференциация социальной защиты населения

Как результат агрегированный анализ максимальных и минимальных значений рассматриваемых показателей в абсолютном и относительном выражениях (табл. 4) свидетельствует о частичном совпадении позиций регионов по их максимальным и минимальным значениям. Признанными лидерами по максимальным показателям являются Краснодарский край, Ростовская область, Волгоградская область, аутсайдерами - Республика Калмыкия, г. Севастополь и Республика Адыгея.

Анализ дифференциации денежных размеров мер социальной защиты населения ре-

Таблица 4

\section{Поляризация регионов ЮФО с максимальными и минимальными значениями абсолютных и относительных показателей численности населения в 2016 г.}

\begin{tabular}{|c|c|c|c|c|}
\hline \multirow[b]{2}{*}{ Группы населения } & \multicolumn{2}{|c|}{ Регионы с min показателем } & \multicolumn{2}{|c|}{ Регионы с max показателем } \\
\hline & $\begin{array}{l}\text { по числен- } \\
\text { ности }\end{array}$ & $\begin{array}{l}\text { по доле от } \\
\text { населения }\end{array}$ & $\begin{array}{l}\text { по числен- } \\
\text { ности }\end{array}$ & $\begin{array}{l}\text { по доле от } \\
\text { населения }\end{array}$ \\
\hline Население, всего & РКя & РКя & KK & KK \\
\hline Население, занятое в экономике & РКя & РКя & KK & $\mathrm{AO}$ \\
\hline Население-пенсионеры & РКя, C, РA & PA & KK & PKя \\
\hline $\begin{array}{l}\text { Население младше трудоспособного } \\
\text { возраста }\end{array}$ & РКя & $\mathrm{C}$ & КК & РКя \\
\hline Население трудоспособного возраста & РКя & РКм & KK & $\mathrm{PO}$ \\
\hline $\begin{array}{l}\text { Население старше трудоспособного воз- } \\
\text { раста }\end{array}$ & РКя & РКя & КK & РКм \\
\hline $\begin{array}{l}\text { Дети до } 16 \text { лет с назначенными ежеме- } \\
\text { сячными пособиями }\end{array}$ & $\mathrm{C}$ & $\mathrm{C}$ & КК & РКя \\
\hline Население-инвалиды, всего & РКя & $\mathrm{C}$ & $\mathrm{KK}, \mathrm{PO}$ & $\mathrm{PO}$ \\
\hline Население с I группой инвалидности & $\mathrm{C}$ & $\mathrm{C}$ & KK & РКя \\
\hline Население со II группой инвалидности & РКя & $\mathrm{AO}$ & KK, PO & $\mathrm{PO}$ \\
\hline Население с III группой инвалидности & $\mathrm{C}$ & KK & $\mathrm{KK}, \mathrm{PO}$ & PKя \\
\hline Население - дети-инвалиды & $\mathrm{C}$ & $\mathrm{PO}, \mathrm{C}$ & KK & PКя \\
\hline Население - труженики тыла & РКя, C & KK & $\mathrm{BO}, \mathrm{PO}$ & $\mathrm{BO}$ \\
\hline Население - ветераны труда & $\mathrm{C}$ & $\mathrm{PO}$ & KK & PKя \\
\hline $\begin{array}{l}\text { Население - реабилитированные лица и } \\
\text { лица, признанные пострадавшими от по- } \\
\text { литических репрессий }\end{array}$ & $\mathrm{C}$ & $\mathrm{C}$ & $\mathrm{PO}$ & РКя \\
\hline $\begin{array}{l}\text { Население, получившее региональный } \\
\text { материнский капитал }\end{array}$ & $\mathrm{PA}$ & $\mathrm{PO}$ & $\mathrm{BO}$ & $\mathrm{AO}, \mathrm{BO}$ \\
\hline $\begin{array}{l}\text { Выплаченные единовременные пособия } \\
\text { при рождении ребенка }\end{array}$ & РКя & $\mathrm{BO}$ & KK & КК \\
\hline $\begin{array}{l}\text { Полученные единовременные пособия, } \\
\text { выплаченные женщинам, вставшим на } \\
\text { учет в медицинских учреждениях в ран- } \\
\text { ние сроки беременности (до } 12 \text { недель) }\end{array}$ & РКя & $\begin{array}{l}\text { PA, РКм, } \\
\text { РКя, BO, C }\end{array}$ & КК & КК \\
\hline $\begin{array}{l}\text { Население - получатели ежемесячных } \\
\text { пособий по уходу за ребенком до дости- } \\
\text { жения им возраста } 1,5 \text { лет }\end{array}$ & РКя & РКм, С & KK & PA \\
\hline $\begin{array}{l}\text { Население - получатели ежемесячных } \\
\text { денежных выплат при рождении третье- } \\
\text { го и последующих детей до достижения } \\
\text { ребенком возраста } 3 \text { лет }\end{array}$ & $\mathrm{C}$ & $\mathrm{C}$ & КК & КК \\
\hline $\begin{array}{l}\text { Доля населения с денежными доходами } \\
\text { ниже прожиточного минимума от числа } \\
\text { жителей региона }\end{array}$ & РА, РКя, С & KK & KК, PO & РКя \\
\hline
\end{tabular}

Примечания. РА - Республика Адыгея, РКя - Республика Калмыкия, РКм - Республика Крым, КК - Краснодарский край, АО - Астраханская область, ВО - Волгоградская область, РО - Ростовская область, С - г. Севастополь. Цветом выделено совпадение тіn или тах категорий как по численности, так и по доле категории населения в его общей совокупности. Совпадающие регионы также выделены цветом. Рассчитано по данным таблиц 2 и 3. 
гионов ЮФО (табл. 5) показал, что по уровню заработной платы населения, среднедушевых денежных доходов и назначенных пенсий наблюдается отставание ЮФО от общероссийских показателей.

Так, уровень заработной платы среднего жителя ЮФО в 2016 г. составил 73 \% от общероссийского уровня (или 26,96 тыс. руб. против 36,7 тыс. руб.); среднедушевые денеж- ные доходы жителей ЮФО составили 85,6 \% от общероссийского уровня (26,3 тыс. руб. против 30,7 тыс. руб.), размер назначенных пенсий в ЮФО составляет $94 \%$ от общероссийского уровня (16,4 тыс. руб. против 17,4 тыс. руб.). В структуре доходов среднестатистического россиянина, по сравнению с жителем ЮФО, социальные выплаты значат больше: почти $20 \%$ против $19 \%$ соответственно.

\section{Размеры основных мер соцзащиты населения регионов ЮФО \\ и Российской Федерации в 2016 г., руб. в мес.}

\begin{tabular}{|c|c|c|c|c|c|c|c|c|c|c|c|c|}
\hline Мера соцзащиты & РФ & ЮФО & PA & РКя & PКм & KK & $\mathrm{AO}$ & $\mathrm{BO}$ & PO & $\mathrm{C}$ & $\min$ & $\max$ \\
\hline $\begin{array}{l}\text { Среднедушевые де- } \\
\text { нежные доходы * }\end{array}$ & 30744 & 26308 & 23600 & 14569 & 18071 & 32785 & 22760 & 20739 & 27104 & 24937 & РКя & КК \\
\hline $\begin{array}{l}\text { Потребительские } \\
\text { расходы в среднем * }\end{array}$ & 22468 & 21104 & 17817 & 7441 & 13585 & 27018 & 17684 & 16088 & 21843 & 21050 & РКя & КК \\
\hline $\begin{array}{l}\text { Среднемесячная } \\
\text { номинальная начис- } \\
\text { ленная аработная } \\
\text { плата работников * }\end{array}$ & 36709 & 26964 & 23109 & 21318 & 24140 & 28734 & 27493 & 26554 & 26689 & 24259 & РКя & КК \\
\hline $\begin{array}{l}\text { Общий прожиточ- } \\
\text { ный минимум на } \\
\text { душу населения }\end{array}$ & 8866 & - & 8509 & 9542 & 9884 & 9257 & 9181 & 9625 & 10005 & 8866 & PA & PO \\
\hline $\begin{array}{lr}\text { Прожиточный } & \text { ми- } \\
\text { нимум } & \text { трудоспо- } \\
\text { собного } \\
\text { ния ** }\end{array}$ & 9458 & - & 8899 & 10210 & 10685 & 9741 & 9858 & 10232 & 10711 & 9458 & PA & $\mathrm{PO}$ \\
\hline $\begin{array}{l}\text { Прожиточный ми- } \\
\text { нимум пенсионе- } \\
\text { ров ** }\end{array}$ & 7294 & - & 6828 & 7878 & 8208 & 7492 & 7464 & 7809 & 8239 & 7294 & $\mathrm{PA}$ & $\mathrm{PO}$ \\
\hline $\begin{array}{l}\text { Прожиточный ми- } \\
\text { нимум детей ** }\end{array}$ & 8962 & - & 8620 & 10030 & 9452 & 9938 & 9284 & 10078 & 10487 & 8962 & PA & $\mathrm{PO}$ \\
\hline $\begin{array}{l}\text { Прожиточный ми- } \\
\text { нимум пенсионера } \\
\text { для установления } \\
\text { социальной допла- } \\
\text { ты к пенсии по } \\
\text { субъектам РФ } \\
\end{array}$ & 8540 & - & 8138 & 7667 & 8410 & 8478 & 7665 & 8535 & 8488 & 8532 & $\mathrm{AO}$ & $\mathrm{BO}$ \\
\hline $\begin{array}{l}\text { Средний размер на- } \\
\text { значенных пенсий }\end{array}$ & 17426 & 16405 & 15886 & 15585 & 16543 & 16408 & 15975 & 16641 & 16283 & 17644 & РКя & $\mathrm{C}$ \\
\hline $\begin{array}{lr}\text { Средние } & \text { назначен- } \\
\text { ные } & \text { социальные } \\
\text { пенсии } & \text { детей- } \\
\text { инвалидов до } 18 \text { лет } \\
\end{array}$ & 17837 & 16950 & 16904 & 18040 & 16889 & 16900 & 16935 & 16904 & 16929 & 16904 & РКм & РКя \\
\hline $\begin{array}{l}\text { Средний размер } \\
\text { единовременной } \\
\text { денежной выплаты } \\
\text { в виде региональ- } \\
\text { ного материнского } \\
\text { капитала }\end{array}$ & 75395 & 68409 & 50000 & 62349 & - & 85766 & 58192 & 47624 & 115475 & - & $\mathrm{BO}$ & $\mathrm{PO}$ \\
\hline $\begin{array}{l}\text { Размер базового } \\
\text { ежемесячного по- } \\
\text { собия на ребенка }\end{array}$ & - & - & 115 & 225 & 532 & 181 & 214 & 317 & 374 & 532 & PA & C, РКм \\
\hline $\begin{array}{l}\text { Базовое ежемесяч- } \\
\text { ное пособие на де- } \\
\text { тей одиноких ма- } \\
\text { терей }\end{array}$ & - & & 230 & 450 & 1596 & 355 & 328 & 634 & 748 & 1596 & $\mathrm{PA}$ & C, РКм \\
\hline $\begin{array}{l}\text { Базовое ежемесяч- } \\
\text { ное пособие на де- } \\
\text { тей военнослужа- } \\
\text { щих по призыву }\end{array}$ & & & 172 & 338 & - & 262 & - & 476 & 561 & - & PA & $\mathrm{PO}$ \\
\hline
\end{tabular}


Н.В. Горшкова, Л.А. Мытарева, Л.В. Григорьева. Дифференциация социальной защиты населения

Окончание таблицьь 5

\begin{tabular}{|l|c|c|c|c|c|c|c|c|c|c|c|c|}
\hline \multicolumn{1}{|c|}{ Мера соцзащиты } & РФ & ЮФО & РА & РКя & РКм & КК & АО & ВО & РО & С & min & max \\
\hline $\begin{array}{l}\text { Базовое ежемесяч- } \\
\text { ное пособие на де- } \\
\text { тей, родители кото- } \\
\text { рых уклоняются от } \\
\text { уплаты алиментов }\end{array}$ & - & - & 172 & 338 & 798 & 262 & - & 476 & 561 & 798 & РА & С, РКм \\
\hline $\begin{array}{l}\text { Средняя ежемесяч- } \\
\text { ная денежная. вы- } \\
\text { плата при рожде- } \\
\text { нии третьего и по- } \\
\begin{array}{l}\text { следующих детей } \\
\text { до достижения ре- } \\
\text { бенком возраста } \\
\text { трех лет }\end{array}\end{array}$ & 865316 & - & - & 10238 & 9655 & - & 7693 & 7704 & 9634 & ВО & РКм \\
\hline $\begin{array}{l}\text { Средний размер } \\
\text { выплаты тружени- } \\
\text { кам тыла }\end{array}$ & 684 & 668 & 1135 & 200 & 500 & 707 & 326 & 638 & - & 532 & РКя & РА \\
\hline $\begin{array}{l}\text { Средний размер } \\
\text { выплаты ветеранам } \\
\text { труда }\end{array}$ & 541 & 518 & 1070 & 200 & 500 & 487 & 490 & 529 & - & 532 & РКя & РА \\
\hline $\begin{array}{l}\text { Средняя выплата } \\
\text { реабилитирован- } \\
\text { ным лицам и ли- } \\
\text { цам, признанным } \\
\begin{array}{l}\text { пострадавшими от } \\
\text { политических ре- } \\
\text { прессий }\end{array}\end{array}$
\end{tabular}

Примечания. РА - Республика Адыгея, РКя - Республика Калмыкия, РКм - Республика Крым, КК - Краснодарский край, $\mathrm{AO}$ - Астраханская область, ВО - Волгоградская область, РО - Ростовская область, С - г. Севастополь. * - по данным: [7]; ** - прожиточный минимум на 1-й кв. 2017 года. Составлено авторами по: [8].

Величина ВРП, являясь обобщенным показателем, характеризирующим уровень развития экономики, в 2016 г. в ЮФО составила 4 590,6 млрд руб., что соответствует $7 \%$ от ВВП России за этот же период.

В региональном разрезе экономические ресурсы субъектов ЮФО (см. табл. 6) неоднородны. Так, наибольшим ресурсным потенциалом располагают Краснодарский край, Ростовская и Волгоградская области, которые имели по итогам 2015 г. (самые свежие данные Росстата на 1 февраля 2018 г.) ВРП, равные 1946, 1172 и 735 млрд руб. соответственно. При этом доходы их консолидированных бюджетов составили 263,3 млрд руб. в Краснодарском крае, 190,9 млрд руб. в Ростовской области и всего 101,5 млрд руб. в Волгоградской области (для сравнения ВРП Республики Крым составил 248,3 млрд руб., а доходы республиканского консолидированного бюджета - 116,7 млрд руб.). При этом в 2015 г. профицит консолидированных бюджетов субъектов Федерации, входящих в состав ЮФО, был только у Республики Адыгея, Краснодарского края и Ростовской области, в остальных субъектах наблюдался бюджетный дефицит.

Как мы видим, финансовые и ресурсные возможности у регионов ЮФО неравны. Помимо рассмотренных мер социальной защиты, региональные власти поддерживают отдельные категории населения посредством предоставления социальных и налоговых льгот по региональным и местным налогам.

В результате многочисленный ряд минимальных социальных гарантий федерального, регионального и местного уровней как в ЮФО, так и во всей России крайне незначителен по средним суммам в расчете на одного получателя. Среди мер поддержки семей с детьми - ежемесячные мизерные детские пособия, которые во многих регионах составляют 90-150 руб. в месяц, различные целевые выплаты школьникам на питание в школе, компенсации на оплату услуг в дошкольных учреждениях, «праздничные» выплаты к Новому году, Дню семьи, 1 сентября и даже к Пасхе (вне зависимости от вероисповедания и религиозных убеждений), компенсации и льготы на оплату жилья и коммунальных услуг, 
Финансовые ресурсы регионов ЮФО в 2015 г.

\begin{tabular}{|l|c|c|c|c|c|c|c|c|}
\hline \multicolumn{1}{|c|}{ Мера соцзащиты РА } & РКя & РКм & КК & АО & ВО & РО & С \\
\hline ВРП, млрд руб. & 64997 & 4591 & 82,6 & 47,3 & 248,3 & 1947 & 320,7 & 735,3 \\
\hline $\begin{array}{l}\text { Доходы консолидированно- } \\
\text { го бюджета субъекта РФ, } \\
\text { млрд руб. }\end{array}$ & & & & & & & & \\
\hline $\begin{array}{l}\text { Расходы консолидированно- } \\
\text { го бюджета субъекта РФ, } \\
\text { млрд руб. }\end{array}$ & 936,4 & - & 17,7 & 12,2 & 131,3 & 260,9 & 40,5 & 108,1 \\
\hline $\begin{array}{l}\text { Дефицит/профицит бюджета } \\
\text { субъекта РФ, млрд руб. }\end{array}$ & $-12,6$ & - & 0,4 & $-0,6$ & $-14,6$ & 2,4 & $-1,6$ & $-6,6$ \\
\hline $\begin{array}{l}\text { Доля социальных выплат в } \\
\text { общей структуре денежных } \\
\text { доходов, \% }\end{array}$ & 19,1 & 19,9 & 19,5 & 30,9 & 27,2 & 15,9 & 20,1 & 25,8 \\
\hline $\begin{array}{l}\text { Численность населения с } \\
\text { денежными доходами ниже } \\
\text { прожиточного минимума, } \\
\text { млн чел. }\end{array}$ & 19,7 & 0,0 & 0,1 & 0,1 & 0,4 & 0,6 & 0,2 & 0,4 \\
\hline $\begin{array}{l}\text { Доля населения с денежны- } \\
\text { ми доходами ниже прожи- } \\
\text { точного минимума от числа } \\
\text { жителей региона \% }\end{array}$ & 13,4 & - & 13,7 & 31,2 & 22,2 & 11,6 & 16,2 & 15,3 \\
\hline
\end{tabular}

Примечание. Составлено авторами по: [8].

выплаты при рождении ребенка и при достижении им определенного возраста, услуги и льготы в натуральной форме, например лекарственное обеспечение, обеспечение питанием, бесплатный или льготный проезд, льготный отдых и т. д.

Вследствие значительной региональной дифференциации мер социальной защиты россиян их системное представление и сравнение в региональном разрезе для целей выявления и оценки показателей эффективности функционирования региональной системы социальной защиты населения затруднено. В настоящее время идет развитие информационного обеспечения и сопровождения функционирования системы социальной защиты россиян.

Условно мы выделяем два направления такого развития: во-первых, это создание общероссийской информационной базы по всем действующим в России мерам социальной защиты россиян; во-вторых, это унификация и кодификация социального законодательства на уровне субъектов Российской Федерации. Отмеченные направления реализуются на фоне усиления адресности самой системы социальной защиты населения.

Первое направление представлено созданием и запуском с 1 января 2018 г. специализированного общероссийского Интернет-пор- тала «Единая государственная информационная система социального обеспечения» (ЕГИССО, http://www.egisso.ru/). ЕГИССО является информационной системой, позволяющей получать гражданам и органам власти актуальную информацию о мерах социальной поддержки, оказываемых из бюджетов всех уровней, как в отношении отдельно взятого человека, так и в целом по стране, а также получать сведения, необходимые органам власти для предоставления социальной помощи.

Второе направление представлено вводом в действие отдельными субъектами Федерации социальных кодексов [5; 6]. Общепризнано, что в большинстве субъектов Федерации и муниципалитетах одновременно имеют силу несколько десятков нормативных документов, регулирующих социальную защиту населения. Нормативное обеспечение социальной защиты разрознено, громоздко, неоднозначно. Это затрудняет процесс администрирования государственных и муниципальных расходов в этой сфере; существенно снижает прозрачность бюджетного процесса вопреки концепции «открытого бюджета», внедряемой в российскую практику. Сложившаяся ситуация делает недоступным потребление продуктов социальной защиты широкими слоями населения, в большинстве своем не обладаю- 
щими доступом к информации обо всех положенных им мерах, льготах и гарантиях. Налицо острая потребность в кодификации социального законодательства на всех уровнях власти.

Основными целями создания Социального кодекса [13] являются унификация терминологии социального законодательства; усиление адресной составляющей - отработка и внедрение четкого, понятного для людей подхода, на какие меры социальной помощи и при каких условиях возникает у человека право на социальную поддержку; внедрение объективных критериев нуждаемости; увеличение размера социальных выплат для семей с детьми с низким уровнем доходов и тех, кто в силу объективных причин не может самостоятельно преодолеть сложную жизненную ситуацию; повышение эффективности расходования бюджетных средств; гармонизация национального социального законодательства и международного права.

Социальное законодательство кодифицировано (действуют Социальные кодексы территорий) только в нескольких субъектах Российской Федерации: в г. Санкт-Петербурге [12], в Волгоградской области [10], Ярославской области [14], Белгородской области [9], в Ленинградской области [11] (действует с 1 января 2018 года). В этих социальных кодексах территорий закрепляется механизм финансирования социальных расходов в разрезе реализации обязательных и дополнительных мер социальной поддержки и помощи населению. О кодификации социальной защиты населения задумываются и другие территории, например, г. Москва [2], Ханты-Мансийский автономный округ [13]. Заметим, что о необходимости создания Социального кодекса Российской Федерации [15] специалисты говорят с начала 2000-х годов.

Считаем необходимым принятие общероссийского Социального кодекса с полным перечнем всех социальных гарантий, федеральных мер социальной защиты и перечня возможных региональных мер (по аналогии с практикой Налогового кодекса РФ). На региональном и муниципальном уровнях целесообразно принятие соответствующих социальных кодексов.

Помимо кодификации социального законодательства на региональном и федеральном уровнях, считаем обоснованным создание региональных и федеральных «социальных казначейств» как системы, способной объединять данные о различных получателях помощи, что позволит консолидировать информацию обо всех выплатах каждому домохозяйству (семье). Необходимость создания социального казначейства связана с переходом российской системы социальной защиты от уравнительных мер к адресным, поскольку почти 90 \% получателей мер социальной защиты фактически не нуждаются в таковых [4]. Создание социальных казначейств должно сопровождаться внедрением в гражданский оборот в качестве субъекта правоотношений домашнего хозяйства (семьи).

Таким образом, реализация предложенных мероприятий позволит минимизировать региональную дифференциацию предоставляемой социальной защиты, а также будет способствовать развитию в Российской Федерации адресной системы социальной помощи населению.

\section{СПИСОК ЛИТЕРАТУРЫ}

1. Антропов, В. В. Экономические модели социальной защиты населения в государствах ЕС: автореф. дис. ... д-ра экон. наук / Антропов Владислав Владимирович. - М., 2007. - Электрон. текстовые дан. - Режим доступа: https://www.econ.msu.ru/ cmt2/lib/a/886/File/antropov.pdf. - Загл. с экрана.

2. Бахарева, Н. Для Москвы напишут социальный кодекс / Н. Бахарева. - Электрон. текстовые дан. - Режим доступа: http://mosday.ru/news/item. php?930505\&view=full. - Загл. с экрана.

3. Григорьева, Л. В. Экономические механизмы защиты населения от пенсионных рисков как инструмент социально-экономического развития региона / Л. В. Григорьева, Н. В. Горшкова, Л. А. Мытарева // Вестник Волгоградского государственного университета. Серия 3 , Экономика. Экология. 2017. - № 1 (38). - C. 31-44. - DOI: https://doi.org/ 10.15688/jvolsu3.2017.1.4.

4. НИИ Минфина и Всемирный банк: 87 \% получателейльгот и пособий в них не нуждаются. - Электрон. текстовые дан. - Режим доступа: https:// www.miloserdie.ru/news/nii-minfina-i-vsemirnyj-bank-87poluchatelej-lgot-i-posobij-v-nih-ne-nuzhdayutsya/. Загл. с экрана.

5. Обсуждаем проект Социального кодекса Ленинградской области. - Электрон. текстовые дан. - Режим доступа: http://social.lenobl.ru/napdelo/ soc_kod. - Загл. с экрана. 
6. Подготовка социального кодекса РФ - очередной этап кодификации Российского законодательства. - Электрон. текстовые дан. - Режим доступа: http://dis.ru/library/564/25211/. - Загл. с экрана.

7. Регионы России. Основные характеристики субъектов Российской Федерации. 2017 : стат. сб. - М. : Росстат, 2017. - 751 с.

8. Социальное положение и уровень жизни населения России. 2017 : стат. сб. - М. : Росстат, 2017. $-332 \mathrm{c}$.

9. Социальный кодекс Белгородской области : закон Белгородской области от 28 декабря 2004 г. № 165. - Электрон. текстовые дан. - Режим доступа: http://docs.cntd.ru/document/469022331. - Загл. с экрана.

10. Социальный кодекс Волгоградской области : закон Волгоградской области от 31 декабря 2015 г. № 246-ОД (кодекс вступил в силу 1 июля 2016 г.). Электрон. текстовые дан. - Режим доступа: https:// rg.ru/2016/03/26/volgograd-zakon246-reg-dok.html. Загл. с экрана.

11. Социальный кодекс Ленобласти принят. Электрон. текстовые дан. - Режим доступа: http:// www.socialnaya-podderzhka.ru/news/socialnyj_ kodeks_lenoblasti_prinjat_66339/._-Загл. с экрана.

12. Социальный кодекс Санкт-Петербурга : закон Санкт-Петербурга от 22 ноября 2011 г. № 728132. - Электрон. текстовые дан. - Режим доступа: http://subsidii.net. - Загл. с экрана.

13. Социальный кодекс - это реальный инструмент в борьбе с бедностью. - Электрон. текстовые дан. - Режим доступа: http://fedpress.ru/ interview/1716829. - Загл. с экрана.

14. Социальный кодекс Ярославской области : закон Ярославской области от 19 декабря 2008 г. № 65-з. - Электрон. текстовые дан. - Режим доступа: http://docs.cntd.ru/document/934023342. - Загл. с экрана.

15. Фролов, О. П. Социальный кодекс в системе государственной поддержки населения России / О. П. Фролов // Кадры предприятия. - 2013. № 1. - Электрон. текстовые дан. - Режим доступа: http://finpress.ru/library/728/31525/. - Загл. с экрана.

\section{REFERENCES}

1. Antropov V.V. Ekonomicheskiye modeli sotsialnoy zashchity naseleniya $v$ gosudarstvakh ES: avtoref. dis.... d-ra ekon. nauk [Economic Models of Social Protection of the Population in the EU States. Dr. econ. sci. abs. diss.]. Moscow, 2007. URL: https:// www.econ.msu.ru/cmt2/lib/a/886/File/antropov.pdf (accessed January 2, 2018).

2. Bakhareva N. Dlya Moskvy napishut sotsialnyy kodeks [A Social Code Will Be Written for
Moscow]. URL: http://mosday.ru/news/item.php? 930505\&view=full (accessed January 2, 2018).

3. Grigoryeva L.V., Gorshkova N.V., Mytareva L.A. Ekonomicheskiye mekhanizmy zashchity naseleniya ot pensionnykh riskov kak instrument sotsialno-ekonomicheskogo razvitiya regiona [Economic Mechanisms of Population Protection from Pension Risks as an Instrument of Social and Economic Development of the Region]. Vestnik Volgogradskogo gosudarstvennogo universiteta. Seriya 3. Ekonomika. Ekologiya [Science Journal of Volgograd State University. Global Economic System], 2017, no. 1 (38), pp. 31-44. DOI: https://doi.org/10.15688/jvolsu3. 2017.1.4.

4. NII Minfina $i$ Vsemirnyy bank: $87 \%$ poluchateley lgot $i$ posobiy $v$ nikh ne nuzhdayutsya [Research Institute of the Ministry of Finance and the World Bank: $87 \%$ of Recipients of Benefits and Allowances Do Not Need Them]. URL: https:// www.miloserdie.ru/news/nii-minfina-i-vsemirnyj-bank-87poluchatelej-lgot-i-posobij-v-nih-ne-nuzhdayutsya/ (accessed January 2, 2018).

5. Obsuzhdaem proekt Sotsialnogo kodeksa Leningradskoy oblasti [To Discussion of the Draft Social Code of the Leningrad Region]. URL: http:// social.lenobl.ru/napdelo/soc_kod (accessed January 2, 2018).

6. Podgotovka sotsialnogo kodeksa RFocherednoy etap kodifikatsii Rossiyskogo zakonodatelstva [Preparation of the Social Code of the Russian Federation - the Next Stage of Codification of the Russian Legislation]. URL: http://dis.ru/library/ 564/25211/ (accessed January 2, 2018).

7. Regiony Rossii. Osnovnyye kharakteristiki subyektov Rossiyskoy Federatsii. 2017: stat. sb. [Regions of Russia. The Main Characteristics of the Subjects of the Russian Federation, 2017. Statistical Collection]. Moscow, Rosstat Publ., 2017. 751 p.

8. Sotsialnoe polozhenie $i$ uroven zhizni naseleniya Rossii. 2017: stat. sb. [Social Status and Living Standards of the Population of Russia, 2017. Statistical Collection]. Moscow, Rosstat Publ., 2017.332 p.

9. Sotsialnyy kodeks Belgorodskoy oblasti : zakon Belgorodskoy oblasti ot 28 dekabrya 2004 goda № 165 [The Social Code of the Belgorod Region: Law of the Belgorod Region of December 28, 2004 no.165]. URL: http://docs.cntd.ru/document/ 469022331 (accessed January 2, 2018).

10. Sotsialnyy kodeks Volgogradskoy oblasti: zakon Volgogradskoy oblasti ot 31 dekabrya 2015 goda № 246-OD (kodeks vstupil v silu 1 iyulya 2016 g.) [The Social Code of the Volgograd Region: Law of the Volgograd Region of December 31, 2015 no. 246-OD (the Code Entered into Force on July 1, 2016)]. URL: https://rg.ru/2016/03/26/volgograd-zakon246reg-dok.html (accessed January 2, 2018). 
11. Sotsialnyy kodeks Lenoblasti prinyat [The Social Code of the Leningrad Region Has Been Adopted]. URL: http://www.socialnaya-podderzhka. ru/ news/socialnyj_kodeks_lenoblasti_prinjat_66339/ (accessed January 2, 2018).

12. Sotsialnyy kodeks Sankt-Peterburga: zakon Sankt-Peterburga ot 22 noyabrya $2011 \mathrm{~g}$. № 728-132 [The Social Code of Saint Petersburg: Law of Saint Petersburg of November 22, 2011 no. 728132]. URL: http://subsidii.net (accessed January 2, 2018).

13. Sotsialnyy kodeks - eto realnyy instrument $v$ borbe s bednostyu [The Social Code is a Real Tool against Poverty]. URL: http://fedpress.ru/interview/ 1716829.

14. Sotsialnyy kodeks Yaroslavskoy oblasti: zakon Yaroslavskoy oblasti ot 19 dekabrya $2008 \mathrm{~g}$. № 65-z [The Social Code of the Yaroslavl Region: Law of the Yaroslavl Region of December 19, 2008 no. 65z]. URL: http://docs.cntd.ru/document/934023342 (accessed January 2, 2018).

15. Frolov O.P. Sotsialnyy kodeks v sisteme gosudarstvennoy podderzhki naseleniya Rossii [The Social Code in the System of State Support to the Population of Russia]. Kadry predpriyatiya, 2013, no. 1. URL: http:// finpress.ru/library/728/31525. (accessed January 2, 2018).

\section{Information about the Authors}

Natalya V. Gorshkova, Doctor of Sciences (Economics), Professor, Head of Department of Theory of Finance, Credit and Taxation, Volgograd State University, Prosp. Universitetsky, 100, 400062 Volgograd, Russian Federation, gorshkovanv@volsu.ru.

Leyla A. Mytareva, Candidate of Sciences (Economics), Associate Professor, Department of Theory of Finance, Credit and Taxation, Volgograd State University, Prosp. Universitetsky, 100, 400062 Volgograd, Russian Federation, mytarevala@volsu.ru.

Lyubov V. Grigoryeva, Senior Lecturer, Department of Theory of Finance, Credit and Taxation, Volgograd State University, Prosp. Universitetsky, 100, 400062 Volgograd, Russian Federation, grigorievalv@volsu.ru.

\section{Информация об авторах}

Наталья Валерьевна Горшкова, доктор экономических наук, профессор, заведующая кафедрой теории финансов, кредита и налогообложения, Волгоградский государственный университет, просп. Университетский, 100, 400062 г. Волгоград, Российская Федерация, gorshkovanv@volsu.ru.

Лейла Акифовна Мытарева, кандидат экономических наук, доцент кафедры теории финансов, кредита и налогообложения, Волгоградский государственный университет, просп. Университетский, 100, 400062 г. Волгоград, Российская Федерация, mytarevala@volsu.ru.

Любовь Владимировна Григорьева, старший преподаватель кафедры теории финансов, кредита и налогообложения, Волгоградский государственный университет, просп. Университетский, 100, 400062 г. Волгоград, Российская Федерация, grigorievalv@volsu.ru. 